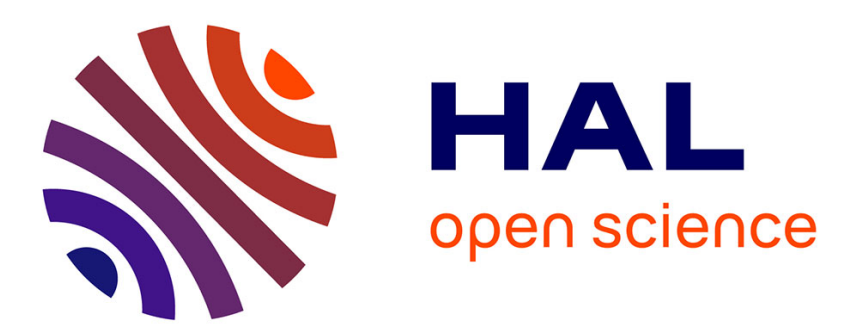

\title{
Peripheral Circulations, Transient Centralities: The International Geography of the Avant-Gardes in the Interwar Period (1918-1940)
}

Béatrice Joyeux-Prunel

\section{- To cite this version:}

Béatrice Joyeux-Prunel. Peripheral Circulations, Transient Centralities: The International Geography of the Avant-Gardes in the Interwar Period (1918-1940). Visual Resources, 2018, pp.1-28. hal01975703

\section{HAL Id: hal-01975703 \\ https://hal.science/hal-01975703}

Submitted on 9 Jan 2019

HAL is a multi-disciplinary open access archive for the deposit and dissemination of scientific research documents, whether they are published or not. The documents may come from teaching and research institutions in France or abroad, or from public or private research centers.
L'archive ouverte pluridisciplinaire HAL, est destinée au dépôt et à la diffusion de documents scientifiques de niveau recherche, publiés ou non, émanant des établissements d'enseignement et de recherche français ou étrangers, des laboratoires publics ou privés. 


\title{
Peripheral Circulations, Transient Centralities. The International Geography of the Avant-Gardes in the Interwar Period (1918-1940)
}

\author{
Béatrice Joyeux-Prunel
}

This paper questions the common historiography about the avant-gardes in the Interwar period, in which Paris is often considered the international avant-garde capital city, with surrealism as its perfect model. It starts with the idea that the history of the avant-gardes (artists and artists' groups who considered themselves or who were considered innovative), could be studied as "a social field", but also an international field structured by mobility. It focuses on the circulation of avant-garde artists and their works, as well as the social, economical, financial, geopolitical and colonial bases of these circulations, to understand how some groups, artists, stories and centers managed to establish themselves better than others. Contrary to the regular narrative based on Parisian domination, a circulatory approach highlights that Paris isolated itself from avant-gardes in the 1920s, unlike the opening of Germany and Central Europe, and that the surrealists themselves were not so international until 1929. Looking at social groups, at their movements and circulation, as well as the various strategies deployed and the underlying geopolitical positions taken by artists after 1929, it shows that from 1929, the Parisian scene, and the surrealist movement in particular, very slowly became a new focus for new artistic generations. Paris only became a global centre of avant-garde circulation after 1934 and surrealism then gradually became the focus of international artists' careers. In this process, artists coming from the peripheries of Europe and the Americas, cultural transfers and resemanticization processes played a central role.

Keywords: Modern Art History; Twentieth Century; Central Europe; Latin America; Spain; Paris; Transnational Art History; Modernism; Canon; Surrealism; Centers and Peripheries; Avant-gardes; Cultural Transfers; Circulation of Art

In the common historiography of the avant-gardes in the Interwar period, Paris is often considered to be the international avant-garde capital, with surrealism as its perfect model. This Parisian centrality in the 1920s and 1930s is supposed to have declined in the 1940s and vanished in the 1950s, a narrative that continues to the benefit of New York. According to the majority of books and articles which never question this idea, with the exile of the leaders of the surrealist movement in 1939-1940, modernity left Paris and Europe with New York subsequently becoming the new world capital of modernism ${ }^{1}$. This canon is questionable. It is based on the assumption that history was guided by a principle of progress and systematic negation, and that this progression took place in one single location. It introduces aesthetics as monoliths, whereas, in reality, artists would go from one movement to another. In other 
words, it naturalizes "isms" which actually took several years to gain recognition. ${ }^{2}$ It also justifies the international domination of a small Parisian elite who are seen as the model of cultural, ethical, and political progress in the history of modern art and culture. This canon produces an incomplete history: it omits avant-gardes born in remote areas, the so-called "peripheries" of modern art history, or those who were not part of canonical groups, such as the abstracts of the 1930s. The history is even more incomplete in regard to those who were considered outside the avant-garde. Finally, the idea of a Parisian centrality in the history of modernism before 1940 is a prerequisite for the idea that New York "stole" modernism from Paris after the 1940s - an interpretation of the global history of art that relies almost exclusively on sources from New York. ${ }^{3}$ According to this assumption, Europe invented nothing new after the 1940s. Neither did anywhere else, in particular, the Eastern side of the Iron Curtain and Latin America, not to mention the African, Asian or Austral no man's land.

A new historiography denies this canon, and demands better recognition for the artistic peripheries. ${ }^{4}$ Some might even claim the superiority of these peripheries over European and US avant-gardes, especially the avant-gardes of Latin America. ${ }^{5}$ However, whether we choose this canon or its opposite, the map in the background remains binary: a center and its peripheries. An axiological analytical grid is also used to characterize the avant-garde: political and social commitment, moral emancipation, new aesthetic and artistic propositions, social and political intelligence of the political and gendered power games of the time, political engagement, etc. This grid has favoured the historiography of surrealism and Dada since the 1930s and the 1950s. It conceals the economic and social spread of the groups that were considered to be the vanguard which was supported by a real, solid international and sustainable market; a dynamic, international artistic press; an elitist, financial, industrial and often colonialist social stance. For example: why did surrealist artists live so comfortably during the Great Depression, while their abstract peers were starving?

It is interesting to re-examine how this canon, which is both celebrated and defended today, has established itself and established a certain geopolitics that has much to answer for. To start with, one can ask how might the mobility of the avant-gardes have led to the victory of Paris and surrealism in art history? International mobility was a means for artists to negotiate their esthetic affiliations in order to claim their place in the art world; this had repercussions on individual, collective, local and global scales. This paper thus starts with the idea that the history of the avant-gardes could be studied as "a social field", ${ }^{6}$ but a field structured by mobility. This field has always been international despite the interference of national, local, and regional forces on the one hand, and despite the diversity of political and economic issues on the other, which can be contradictory. By focusing on the circulation of avant-garde artists and their works, as well as the social, economical, financial, geopolitical and colonial bases of these circulations, and on the cultural transfers and resemanticizations that took place in the circulation, we can understand how some groups, artists, stories and centers managed to establish themselves better than others. Contrary to the regular narrative based on Parisian domination, a circulatory approach highlights the isolation of Paris in the 1920s. It demonstrates that the French capital isolated itself from avant-gardes, unlike Germany and Central Europe wich were more open, and confirms that the surrealists themselves were not so international until 1929. Looking at social groups, at their movements and circulation, as well as the various strategies deployed by artists and their underlying 
geopolitical positions it also shows how the Parisian scene, and the surrealist movement in particular, slowly became the focus for new artistic generations after 1929. Paris became a global centre of avant-garde circulation only after 1934. In this process, the role of artists from the peripheries of Europe and the Americas was central, especially for the progressive domination of surrealism in international artists' careers.

\section{The international avant-gardes in the 1920s: a relative centrality of Paris}

The international field of the avant-gardes can be reconstituted through tracking the global circulation of artists and their art. A collective study of artists' biographies and trajectories, an analysis of their references and preferences, and an exhaustive cartography of the foundation of modernist journals in the 1920s brings into question the idea of a Parisian centrality. The results of the distant, geographic global approach have been published elsewhere, based on prosopographic and cartographic indicators applied to comparable sets of sources, mainly journals, exhibition catalogues and artists' biographies taken from the 1920s. ${ }^{7}$ This paper will focus instead on a complementary approach, that of the middle-scale and micro-scale level.

\section{Artists' Movements and Parisian Disappointment after 1920}

In the aftermath of the 1914-18 war, the idea of the centrality of Paris was entrenched among the European avant-gardes. The avant-garde artists who had left Paris in 1914 returned or came from all over the world, including Piet Mondrian (1872-1944) from The Netherlands, Joan Miró (1893-1983) from Catalonia, Tarsila do Amaral (1886-1973) from Brazil, Joaquín Torres García (1874-1949) from Uruguay, Max Ernst (1891-1976) from Germany, Man Ray (1890-1976) from the USA. Their aim was to learn up-to-date modern art, to become avantgarde artists, and to gain renown. They were inspired by one model: Pablo Picasso (18811973) who became the most well-known artist from the avant-garde in Europe from 1912. ${ }^{8}$ But from 1920, more and more artists became disillusioned, especially foreigners who faced too many obstacles in Paris. In February 1920 Mondrian decided to stop painting. ${ }^{9}$ Miró, marginalized from the Parisian art scene, joined other artists who were revolted by cubism and its narrowness, - this included André Masson (1896-1987), Élie Lascaux (1888-1968), and Jean Dubuffet (1901-1985) among others. Painters lived in a serious crisis of generational renewal in Paris, like writers. ${ }^{10}$ Among newcomers, the Parisian Dada group experienced this crisis when they were about to fight for the etiquette of "surrealism" after 1924. From 1923-1924, the turmoil was at its peak: young poet André Breton (1896-1966) announced that he would not write anymore; his friend Paul Éluard (1895-1952) disappeared; Dubuffet gave up painting and returned to the family wine trade near Bordeaux; in 1923 Mondrian, discouraged because he had to paint flowers to survive (Figure 1), decided to give up painting and return to his homeland. His friends managed to make him change his mind after organizing a "Mondrianlotterie" in Holland to gather money for the penniless painter. ${ }^{11}$ Some left Paris altogether such as the Dutch painter Theo Van Doesburg (1883-1931), the Russian sculptor Alexander Archipenko (1887-1964), the Mexican painter Diego Rivera (1886-1957), and his Uruguyayan colleague Torres García.

Please insert Figure 1 here Mondrian, flower 
In the early 1900s, it had been possible for Parisian artists to have an international career with the help of critics, poets, and dealers, but without fully depending on them. Yet now the main Parisians linked to the international scene were either dead, such as the poet and art critic Guillaume Apollinaire (1880-1918), in exile (art dealers Daniel Henry Kahnweiler (1884-1979) and Wilhelm Uhde (1874-1947), artists Robert Delaunay (1885-1941) and Marcel Duchamp (1887-1968)), or were dedicated to furthering their own careers. Germany, which had been the main international channel and outlet for Parisian modernism in the 1900s and 1910s, ${ }^{12}$ was an inaccessible country after the war. Henceforth, Parisian artists had to take their first steps in new galleries which were rarely open to innovation and preferred a "classic" modernity, and they had to settle for their limited international network. Art dealers were looking for tame modern art, like the conservative fauvism of André Derain (18801954), the worldly colours of Kees Van Dongen (1877-1968), or the consolidated cubism of Georges Braque (1882-1963). ${ }^{13}$ The marketplace also started to favor "primitivism" and "naïve art". Innovation did not sell.

Artists who had money would pay for the right to exhibit, in particular in Montparnasse. It was better to be rich such as the Brazilian Tarsila do Amaral, who could adapt to the new fashions and pictorial trends of the period thanks to the profits of her family plantations. ${ }^{14}$ The social spaces of the literary or national community, such as restaurants and small galleries, were accessible to artists without money, but rarely helped them sell. Many preferred to return home, to the so-called peripheries, where markets were already established.This was the case for Berlin, Brussels, Barcelona, Mexico, and Buenos Aires, and soon for an increasing number of metropolises. Many former foreign cubists, who remained in Paris, gave up Fine Arts for architecture, interior design and the decorative arts, cinema, sets, photography, and graphic design. ${ }^{15}$

From 1920, the circulation of European avant-gardes was no longer centered on Paris. People would travel to discover which places were most suitable to establish themselves. The abstract painter Theo van Doesburg's circulation was evidence of this trend (Figure 2).

By 1923, after months of travel and artistic encounters in Europe, Van Doesburg wrote to his friend Piet Mondrian: "In Paris everything is completely dead (...) For me it is certain that the new cultural zone is the North". 16

Many artists, such as Van Doesburg, went to Germany, oscillating between Weimar and Berlin. From 1922 to 1924, Van Doesburg frequently returned to Weimar and the Bauhaus, where debate was alive. Van Doesburg settled there in his own studio, established a course, attracted students and followers and recruited contributors for the magazine De Stijl. After 1924, his international activism became more oriented toward Berlin, Hannover and Central Europe. With the Soviet persecution of the avant-gardes, there were more and more Russians in Berlin from 1922-23 and constructivist gatherings and groups were dynamic. However, it was also a time of constant mobility, according to the opportunities presented. The circulation of Alexander Archipenko illustrates this transitional situation. The Russian sculptor arrived in Paris in 1909, he joined the cubist network and his career became internationalized from 1912 onwards. However after 1918, his most interesting exhibitions took place outside Paris. ${ }^{17}$ In 1921, Archipenko went to Berlin where he opened a school, got married, and found help and support from critics, dealers, and artists. ${ }^{18}$ He was popular even in Hungary and Croatia. ${ }^{19}$ 
However, in 1923 Archipenko sailed to New York, where he settled permanently. He declared upon his arrival:

America is the only country not jaded and rent by war. It is the land where the great art of the future will be produced. America fires my imagination more than any other country and embodies more of that flexibility, that yeastiness, which means life and vitality and movement. ${ }^{20}$

Thanks to the extensive network of art collector Katherine Dreier (1877-1952), Archipenko set up a school in Manhattan. He was not the only one who no longer needed Paris; neither did Duchamp, Rivera, nor Van Doesburg and many others.

Many artists decided to go where artistic innovation was thriving. They would travel more frequently between Weimar, Berlin, and the capitals of Central Europe, which were more open to abstract innovation than Paris. These cities offered an alternative and social model to that which dominated Paris: Whereas the Parisian market was focused on unique works and signatures, the new European cities formed an integrated chain of schools (such as the Bauhaus and its Hungarian equivalent), workshops, and shops, which led to orders of architectural designs and decorations. The work was then collective. The aim was to pass on, serve, and make oneself understood.

Please insert Figure 2 here (Map of Van Doesburg's circulation)

\section{The Dynamism of the Peripheries}

Outside Paris, the so-called peripheries were likely to be more open to new groups and innovative artists than the Parisian little modernist milieu. Indeed, the geography of the European vanguardist nebula in the Interwar period, with its careers, rivalries, and networks, is very polycentric, as shown by the successive cartographies which correspond to the creation of modernist journals in the 1920s. ${ }^{21}$ For Paris, innovative activity remained important but was not predominant. Whereas the avant-garde journals related to the Dadaist vogue were buried in Paris in 1922, they abounded in Cologne, Hanover, Zurich and Berlin, and in Cracow, Munich, Vienna, Prague and Zagreb. The persistent creation of new journals in the so-called peripheries until the end of the 1920s occurs in parallel with the social and commercial setting of avant-gardism in these different places, despite the arrival of conservative regimes in many cases. Even in Brazil, a market started for artistic innovation. In Paris, on the contrary, avant-gardism became banal. The Dadaists repeated in their correspondence and their journals: the audience is tired, it doesn't expect anything. ${ }^{22}$ The Parisian artistic circle, with certain exclusions, did not even seem to have the desire to be avant-garde anymore, except from some new titles: Esprit nouveau, led by Amédée Ozenfant (1886-1966) and Charles-Edouard Jeanneret (Le Corbusier, 1887-1965), the founders of the Purism movement. As for the future surrealists (better known as Dadaist or as the Groupe de Littérature), they were and considered themselves primarily a literary movement.

An analysis of the content of international modernist magazines' and their geopolitics confirms the isolation of Parisian groups and the non-Parisian orientation of peripheral journals' references and contributors. ${ }^{23}$ The list of the most shared contributors and most 
reproduced artists by the Central European reviews does not show a domination of references coming from Paris. The pool of reproduced artists is aesthetically and geographically varied, from the Bauhaus to the Dutch neoplacticist avant-garde, from cubism and purism to Russian suprematism, to Dada, and to the German "New Objectivity". The careers of the most cited artists in Central European journals led sometimes to Paris, but more often to Berlin, Weimar, and even Moscow. Among the Parisians, those who were most mentioned by Central European journals were Fernand Léger (1881-1955), Archipenko, and also Russian-born painter Louis Marcoussis (1878-1941). These artists were actually leaving the Parisian scene to go abroad, because of insufficient exposure in Paris. Moreover, on this international map, the French scene was isolated along with surrealism.

The Parisian movement most closely linked to the international avant-garde were the purists. Some described their journal, Esprit nouveau, as "The cosmopolitan body well appreciated by the people of Montparnasse and widespread in the Bolshevik friendly circles from all over the world" 24 . Esprit nouveau indeed depended on an international readership. ${ }^{25}$ Its publishers were willing to expand with an American version in 1921. ${ }^{26}$ However, the purists were marginalized in Paris. Maybe their interest in foreign art and architecture was too strong in the xenophobic context of Parisian modern art. Almost every issue featured a special article on a foreign country - mostly towards the East, as can be seen from the 1924 section untlitled « à l'étranger », which included articles on Hungary (No. 21, 1924), Russia (No. 22), Rumania (No. 23), Latvia (No. 25), and Germany (No. 27) - and exposed a list of partnerjournals disseminated all over Europe (Figure 3).

\section{Insert Figure 3 here (page of Esprit nouveau)}

As for the surrealists, until 1926 they were still obsessed with literary and political strategies, hence their weak international exposure (except from the French-speaking parts of Belgium after 1926).

For the international avant-gardes, Germany was quickly considered the most dynamic region: the industrial and fine arts held the promise of a revolution, which would be formal, social, and political and also provide a potential marketplace. Germany also opened institutions dedicated to the transmission of vanguard knowledge. In 1923 Ludwig Hirschfeld Mack (1893-1965), a former student of the Bauhaus, discussed the matter with Parisian painter Fernand Léger: France, which was democratic for a long time, came out victorious from the war, and the avant-garde movement was born there; so why couldn't the French open an institution as strong as the Bauhaus, Hirschfeld Mack wondered. Léger's answer was that the chauvinism and the reactionary spirit of a country intoxicated by its victory, led to a situation which could not be favorable to innovation. Léger also highlighted how much the French avant-gardes envied the German situation. ${ }^{27}$

Some, from Picasso to Miró, would keep on working within the traditional Pariscentered system, which was organized by a mercantile society which liked collecting and was convinced of the high value of easel paintings. They had the support of art journals which praised "the love of art" (such as the magazine L'Amour de l'Art); their ultimate goal would be a place in a museum. Others would turn towards a second international field, where values, institutional and industrial support, and artists' ambitions were very different from what was known in Paris. This other field was polycentric, led by circles which were considered "peripheral". Artists became members of a group and the group mattered more than the artist 
him/herself. Artists were to serve the people. The aim was also to nurture future generations of artists, through the creation of workshops, the organization of conferences, exhibitions, and showing-rooms. From 1922 until 1928, visual artists who did not come from Paris and who wanted to hold a position as avant-gardes clearly increased the value of the transnational space of constructivism.

\section{Works, Texts, and Receptions: The Appeal of the Peripheries}

The non-centrality of Paris is confirmed by the study of works and aesthetics, where we can see the importance of references coming from "the peripheries" of the modernist Europe. Around 1926, artists based in Berlin, Weimar, Cologne, Prague, Vienna, Budapest, Milan, but also Barcelona drew their inspiration from De Chirico's Pittura Metafisica, Italian futurism, geometrical abstraction, the Bauhaus, Russian constructivist art reproductions seen in various reviews, and the constructivist iconography of "the machine age", and even from the German New Objectivity. They did not need Parisian cubism anymore, and fauvism even less.

In Paris, plastic arts were not innovative, unlike the literary, musical or decorative arts. The Parisian inner circle remained very self-centered, as can be seen from modern journals of that time. Indeed with the exception of Le Corbusier's journal, Esprit Nouveau, these journals were very patriotic, hostile to German arts, jealous of Italian artists, rarely interested in Russian arts, and ignorant of foreign arts. In Spain, even Salvador Dalí (1904-1989), then a vanguardist in training, living between Madrid and Barcelona, was influenced as much by Valori Plastici and New Objectivity as he was inspired by Picasso.

In Paris, despite the International Exhibition of decorative arts held in 1925, innovative artists struggled to gain recognition. In 1925, the closing of the review Esprit Nouveau deprived the abstracts of a forum. ${ }^{28}$ In the French capital, constructivist art exhibitions remained few. They were organized by small unestablished galleries ${ }^{29}$ and were not well received, eventhough the art market was expanding. In Paris, only a few painters were welcomed by André Breton and his surrealist group and this was only after 1926, when they had managed to carve out a place for themselves in the right galleries. As for Central European artists, Kristztina Passuth's book on the Central European avant-gardes ends with a litany of names of those who tried to be part of the Parisian life without any success: The Hungarians Lajos Kassák (1887-1967) and Béla Uitz (1887-1972); the Romanians Marcel Janco (1895-1984), and Ion Vinea (1895-1964); the Polish Henryk Berlewi (1894-1967); the Croatians Ljubomir Micić (1895-1971) and Virgil Poljanski (1898-1947). The xenophobic atmosphere of that time also fostered the isolation of foreigners in Paris. ${ }^{30}$ The art market disliked cubism and abstract forms. Many former cubists, even among the French, ended up adopting naturalist, figurative trends, which was the case with the Hungarian sculptor József Csáky (1888-1971), ${ }^{31}$ the Russian-Born painter Léopold Survage (1879-1968), and the former cubist painter Jean Lurçat (1892-1966), and even for Fernand Léger, Le Corbusier and their purist colleague Ozenfant. ${ }^{32}$

The foreign abstract artists who stayed in Paris tried to join forces: in 1929, van Doesburg met the Uruguayan painter Joaquín Torres García for that reason and together they founded Cercle \& Carré ${ }^{33}$ They could only gather artists who were not well established in the Parisian market. French (or French-speaking) abstract artists who stayed with them in Paris were outnumbered and very young like Michel Seuphor (1901-99). By 1930 it was too 
late for abstraction. Neither Cercle \& Carré nor the subsequent abstract group AbstractionCréation had the appeal of surrealism that had suddenly become the most interesting vanguardist position in the international field of modernism.

\section{The victory of Surrealism and Paris: cultural transfers, resemanticizations, and social adaptations}

In art histories, the birth of surrealism is often set in 1924. However in 1924 everyone claimed to be a "surréaliste" in literary Paris. André Breton and his friends had to fight, in both senses of the word, to confiscate the label until 1925. Moreover, barely any artist held any interest in surrealism until 1929. The movement was primarily a literary one, and it was seen as an extremely demanding label, which only a few plastic artists were willing to be affiliated to. When artists joined surrealism, which was the case of Joan Miró and Max Ernst, it was a matter of chance, or it could even be by default or failure. These artists did not want to be associated too long with the Surrealists. However, with the help of the Surrealist writers, Miró and Ernst were able to gain acceptance into the most selective networks of Paris and both painters benefited from the growth of the art market after 1925. The combined influence of entrance to an elite social network and a buoyant art market trigged an interest in surrealism among some artists. Salvador Dalí's dazzling career also contributed especially during the Great Depression, after 1932.

\section{Salvador Dalí, from the Pittura Metafisica to Surrealism}

The trajectory ofo Dalí's career can be seen as an accelerated version of the history of art. In the catalogue raisonné of his works, we can see him, although always late, moving from impressionism to futurism, then to cubism before embracing purism. ${ }^{34}$ In 1918 , he was still admiring "the great French impressionists, Manet, Degas, Renoir". ${ }^{35}$ He realized only around 1921 that impressionism, fauvism, and the cubism of Cézanne had become outmoded. In 1922, he gained admission to the Academy of Madrid and joined the Residencia de Estudiantes, where Luis Buñuel (1900-1983) and Federico García Lorca (1898-1936) led a small group of young modern artists and writers. But at the Academy, Dalí painted his cubofuturistworks in secret. He would read the French communist newspaper L'Humanité, and would walk around with Esprit nouveau and Valori Plastici tucked under his arm because it looked good. In Madrid, the literary avant-garde gathered under the banner of the Ultra movement. Among its leaders, the poet Gillermo de Torre (1900-1971), "our equivalent of Marinetti”, as Dali would later say. The ultraists admired Marinetti's futurism, its centrifugal and dynamic compositions and praised a constructivist-type art (iron towers, aeroplanes, and transatlantic liners). This was far removed from the Parisian version of modernity.

Indeed, whereas Freudian ideas were making their way into Spain, surrealism when it started to be known was considered a literary group, without any proper plastic art proposals. In 1925-26 Dalí was still swaying from one style to another: cubist still lives, Venus inspired by the neo-classical French painter Jean-Dominique Ingres (1780-1867), portraits reminiscent of those from the German New Objectivity ${ }^{36}$, Italian Pittura Metafisica inspired by Giorgio De Chirico (1888-1978)... Having ended up leaving the Academy, Dalí gradually planned to become famous, encouraged by his friends Buñuel and Lorca. He came to Paris in April 
$1926,{ }^{37}$ visited Picasso, and realized that classicism was old-fashioned. Right after his trip to Paris, he imported elements from Miró's style into his own paintings. However, Dalí did not cross the line towards surrealism. He would still borrow from a range of artistic styles: New Objectivity, cubism, Jean Arp's (1886-1966) and Mirós' abstract forms, De Chirico, ${ }^{38}$ "machine age" and ocean liners, architectures from Le Corbusier, and Picasso, as in his 1926 Composition avec Trois personnages (Acadèmia neocubista) (Figure 4). ${ }^{39}$ In 1927, he reproached García Lorca for forgetting to mention airplanes in his poetry. ${ }^{40}$ In March 1928, he signed an eclectic "Anti-artistic Manifesto", reminiscent of Futurism and Dada. ${ }^{41}$ Dalí read La Révolution surréaliste as well. He analyzed its reproductions, especially those by Yves Tanguy (1900-55): skies on desert lands, levitating objects, smoke, ectoplasmic shapes, phallic fingers. He later admitted "I snitched everything from Uncle Yves" 42 , but at that time he snitched from every modern trend in Europe. He also began to add to all of these a proper libidinal and scatological repertoire including flying breasts, severed arms, putrefying asses, "apparels" and gadgets, allusions to masturbation and sodomy. In Barcelona, the colleagues of l'Amic de les Arts saw Dalí as "the archetypal anti-surrealist". ${ }^{43}$ They were hostile to the Parisian surrealists whom they saw as a "small and sterile group" and as "sad lovers of scandal for scandal sake [sic]." Dalí also underlined his "clear distance between [himself] and surrealism" $" 4$.

\section{Insert Figure 4, Dalí, Acadèmia neocubista}

When Joan Miró came back to Catalonia during the summer of 1927 and paid a visit to Dalí with his gallery owner Pierre Loeb (1897-1964), Dalí's ambitions to gain recognition increased. The young painter was suddenly contaminated by a mimetic desire oriented towards Paris: his desire for fame was positively influenced by new mediators and models he did not know before. ${ }^{45}$ Dalí wrote to Lorca:

[Miró] thinks I am much better than all the young painters in Paris. He wrote to me to tell me that I have everything needed to make a great success. As you may know, he was financially very successful over there. ${ }^{46}$

This is where everything happened: Miró promised him a "great career [...] in Paris" according to Dalí. Indeed, Miró's dealer Pierre Loeb advised Dalí not to sway from one trend to another. In his articles for Spanish journals, Dalí started then to endorse surrealism, as if he was hoping to be co-opted by the group. The turning point happened when his painting Dialogue sur la plage was refused from the Autumn Show in 1928 in Barcelona, and when the art dealer Josep Dalmau (1867-1937) stopped supporting Dalí because he was worried about having to close for gross indecency. At this time Dalí referred to himself as a surrealist for the first time on Barcelonese scene.

For Dalí, becoming a surrealist was part of an international strategy: "my main goal is to contribute to the extinction of the artistic phenomenon and gain international prestige", he said to the Spanish press. ${ }^{47}$ Around 1929, allegiance to surrealism suddenly seemed to be a quicker way to achieve "international prestige" than through abstract art or cubism. Things had changed on the international market. The surrealists had become famous (or infamous), albeit disturbing. A couple of other artists were starting to take the same direction, such as the 
Romanian painter Victor Brauner (1903-66) who was also gradually turning towards surrealism and setting aside constructivism. In March 1929, during a trip to Paris, Dalí confirmed his official conversion to surrealism. He came for the filming of Un Chien Andalou, - we know the rest of the story. With this scandal, Dalí simultaneously joined the surrealist network, the worldly circles of lovers of novelties, and the same mercantile network as Miró. In 1929 the new art dealer Camille Goemans (1900-60) offered him a contract.

The surrealist adoption of Dalí was not as easy as it seemed. Dalí indulged in outrageous behaviour and his work was disgustingly provocative; even Breton disliked it. But Dalí was impressive and gaining attention, and he succeeded in turning the "demoralizing project" of surrealism into reality. Papers would talk about it. The public reacted. When he rallied the movement he renewed immediately surrealism which had been in crisis for many years. ${ }^{48}$ Dalí's paintings broadened the horizons of the "pictorial automatism", which were not very conclusive. They shed light on occult obsessions. They were easy to understand and mysterious at the same time. Indeed, he used figurative representation, which was very neat and detailed, along with compositions mixing objects and hybrid bodies, which were both dreamlike and disturbing. They made a lasting impression. Dalí was immediately noticed by the great art lovers. Charles and Marie Laure de Noailles (1891-1981 and 1902-70) bought the most shocking painting from Dalí, Le Jeu Lugubre (private collection). It was the beginning of an unexpected career, which was very profitable for the surrealist group. Indeed, in December 1929, the journal La Revolution surréaliste published the "Second Manifesto" after months of inactivity and internal crisis. The surrealist machine was at work again.

\section{The Dubbing of Surrealism by the International Cream of the Crop}

Dalí was able to survive the economic crisis in the 1930s, thanks to the support of patrons who had started to be interested in surrealism around 1927. ${ }^{49}$ The Noailles paid him well for a new movie, L'Áge d'Or (The Golden Age). ${ }^{50}$ Dalí managed to live comfortably during the Great Depression due to the "Zodiaque Group", which was founded in 1932 by rich aristocrats, real estate owners, and owners or shareholders (or heirs) of oil companies, who were not really affected by the crisis. ${ }^{51}$

The Parisian cosmopolitan aristocracy's support for avant-garde plastic arts was not new. Since the war, avant-garde music, dance, haute-couture, painting and literature, had found their place in this circle, populated by people who loved masked balls, beautiful decorations, collecting, and who competed to achieve greater social distinction. Until 1925, those same patrons had preferred Matisse, Derain or Russian fauvist artists. Then they had turned shortly to the Art déco style. ${ }^{52}$ They would buy carpets, tapestries and hangings made in Algeria for low prices after works by Georges-Henri Rouault (1871-1958), Henri Matisse (1869-1954), Lurçat, Léger, and Le Corbusier - and, after 1927, after Miró. ${ }^{53}$

In theory, the surrealist artists condemned the ideas and aristocratic practices of this circle, as well as the capitalist and colonial sources of their wealth. However some members or former members were very well received, like the writer René Crevel (1900-35). When Miró and Ernst agreed to design the ballet set of Romeo and Juliet for Diaghilev, Louis Aragon (1897-1982) and André Breton protested. ${ }^{54}$ But they themselves had been depending on the funding of the fashion designer Jacques Doucet (1853-1929). They also made a good living from their sales of manuscripts to Charles and Marie Laure de Noailles, and from their 
own brokering activities. ${ }^{55}$ The haute couture also enhanced surrealist paintings since 1927. The Maison Norine of Brussels, for example, introduced Max Ernst's paintings in their catalogue of summer $1927 .{ }^{56}$ Dalí remembered his trip to Paris in 1929, when Miró told him:

You have to get yourself a tailor-made tuxedo. We will have to go out in the worldly circles. [...] When I had my tuxedo, Miró took me for dinner at the Duchess de Dato's. (...) Among the numerous guests, I can only remember the Countess of Cuevas de Vera, who was to become a great friend of mine. ${ }^{57}$

The Countess's Grand Father was John D. Rockefeller (1839-1937), the founder of the Standard Oil Company, then the richest man in the world, and probably the most unbridled capitalist.

Some of Ernsts' or Miró's works could also be found at prestigious collectors' houses. Those collections were exhibited in dealers's galleries, which could foster a mimetic process among collectors. In spring 1929 for instance, the German dealer Alfred Flechtheim (18781937) exhibited Max Ernst in Berlin and Düsseldorf. Known as the specialist of cubism, who had no interest for other aesthetics, Flechtheim still justified why he had chosen to exhibit Ernst whose painting was so different:

Currently the most famous private collections of Paris possess works from the painter of Cologne [...] : [you can find his artworks in the] private collections of Alphonse Kann, Count de Beaumont, Viscount de Noailles, Baron Napoleon Gourgaud, Raoul La Roche, Kelekian, Jacques Doucet, [in] all those who collect Picasso's and other great cubists' works, who also added some of Paul Klee's art pieces, [and also in the collection of] Felix Fénéon who discovered Seurat $[\ldots] .^{58}$

Soon surrealism became a way of life, which was not exclusive to artists. For example, the Noailles were filmed by Man Ray in their villa (Mystères du Château de dé, 1929), with their heads covered with silk tights, exhibiting their prowess as athletes, and with intermittent extracts of poems between these images. At dinner parties held at the Noailles', people would talk like the surrealists, with twisted, even "slimy" vocabulary. After the scandal of L'Âge d'or (The Golden Age), the surrealists understood that they could obtain their strongest support from the "beau-monde", meaning the social elite.

\section{The Dalinian Internationalization of Surrealism}

Whereas in the 1920s the Parisian reference had not been central to painters working outside French-speaking countries, at the beginning of the 1930s however, it became useful to refer to Paris in order to define oneself as avant-garde in the local context; and with a reference to and reverence for surrealism.

This new state of affairs was due to various reasons, both negative and positive. On the one hand, futurist and constructivist references were becoming outmoded in Europe. On the social and economic front, constructivism had lost its momentum as its figureheads became 
ever more integrated into professional structures as teachers, designers, architects, etc. Referring to the Bauhaus was also less subversive than it had been earlier. Croatian vanguardist leader Ljubomir Micić (1895-1971), for instance, who had championed a nationalist version of constructivism until the end of the 1920s and had to realize his marginalization with the crisis of European constructivism, claimed a Parisian affiliation when he published his novel Chevaliers de Montparnasse in $1931 .{ }^{59}$ Moreover, political factors added to the general disaffection felt among young Constructivist artists throughout Europe. Very often, modernists had fled from conservative or protofascist regimes, especially in Germany and Central Europe.

A positive reason for the new Parisian appeal was that it soon became very intriguing and useful to call oneself "surrealist", especially outside France. The surrealist soon became a marker of Parisian approval, justifying the questioning of a local equilibrium. Following Dalí and Brauner who had joined surrealism in 1929, artists that were formerly cubists or constructivists began to call themselves surrealists in other countries in the early 1930s. In Belgrade, Marko Ristić (1902-84) declared himself to be surrealist in 1931. In 1932, a surrealist exhibition was organized in Prague. And on the same year, Argentinian artist Antonio Berni (1905-81) organized an exhibition of surrealist paintings and collages in Buenos Aires $^{60}$. Berni had jumped, suddenly in 1932, from a quite conventional style of modern painting with postcubist inspiration (for instance in his post-1925 matierist nudes and in a 1926-27 Naturaleza muerta con guitarra, prívate collection) and from an art drawing from the German New Objectivity and De Chirico (for instance Toledo y el religioso o El fraile, 1928, private collection), to making pictures of cut-off or ripped out bodies, and paintings of murderers. In 1932 he also added, to his bleeding torsos and trepanned skulls, the evident Dalinian limestone petrification of the body (Figure 4). Around 1934, surrealism won the symbolic competition among international avant-gardes: Artists from South America to Central Europe to Japan to South America started their vanguardist carreer as surrealists.

Insert Figure 5 here : Antonio Berni', Landru

\section{Transnational Crossed Legitimization Processes: Essential Peripheries}

More often, these non-Parisian surrealists were Dalinian surrealists, a phenomenon that cannot be observed in Paris. This gap in the international map of surrealism triggered a global diffusion that had not been possible before, due to Breton's authoritarism and to the group's dissensions - as I shall investigate in this last section.

Despite Breton's attempt to define a Surrealist painting, a claim he reassessed with the publication of Le Surréalisme et la Peinture in $1928,{ }^{61}$ the so-called "surrealist artists" in Paris stood in defiance of Breton's version of surrealism. They preferred indeed not to be labeled surrealists, and exhibited in many different places on the Parisian scene, not hesitating to exhibit with abstract or figurative painters. ${ }^{62}$ Furthermore, claiming to be a surrealist was easier outside Parisas no one would check if Breton had approved the label or not. The surrealist label instantly gave rise to local scandal hence its attractiveness outside France. Reciprocally, foreign self-proclaimed surrealist artists gradually became more useful to the Parisian surrealists as they could help them conquer new marketplaces and because the Parisian surrealists themselves needed wider foreign legitimization. 
The case of Spanish Óscar Domínguez (1906-57) is very telling. In 1933, the painter went back to the Canaries from Montparnasse where he had been well integrated in the École de Paris. He organized a surrealist exhibition in Santa Cruz in Tenerife, independently from the Parisian Surrealists who did not know him. If at the time he lived in Montparnasse, Óscar Domínguez had introduced himself to the surrealists, as a "montparno" they would have rejected him, manu militari. When he had painted in Montparnasse his work represented everything the surrealists had dismissed - young, well-dressed people playing cards in Parisian restaurants, in flashy citrus-inspired colors with cezannesque faces (Los jugadores de cartas, 1928, private collection); or musicians playing geometric instruments, (Los Musicos, 1928, private collection) (Figure 6). His work exuded a sort of inferiority complex, as if the necessary painting of Parisian subjects and the writing of "PARIS" in capital letters under his own signature on top of the canvas, had been necessary to add value to his weak postcubist painting. At that time Domínguez had probably no other way to associate himself with the successful École de Paris. He was among the sort of painters André Breton had disparaged since 1926 in his articles "Le Surréalisme et la peinture" for La Révolution surréaliste, which had been published as a book in $1928 .{ }^{63}$ At the end of the 1920s he was still part of what Breton called "the continuous scandal of cezanism, of neo-academism or machine age [machinisme]”. ${ }^{64}$ But Dalí's example was inspiring. Having organized a local surrealist exhibition in Tenerife, and having found a real audience with his Dalí-like deliquescent paintings (such as the melting Piano, 1933, private collection, or the half-donkey surmounted by a melting female body in L'épingle de sûreté, 1934, Figure 7), in 1934 Domínguez felt confident enough to make contact with the surrealists. André Breton gladly designated him a surrealist and agreed to open a second, official surrealist exhibition in Santa Cruz. ${ }^{65}$ In May 1935 Breton himself came to Tenerife and underlined the "poetic communion" that linked him to his "dear Óscar Domínguez". ${ }^{66}$ Afterwards, Domínguez came back to Paris where he was now part of the elite surrealist group. In the wake of the Tenerife 1935 exhibition, Breton understood that he had to put in place a systematic internationalization strategy if he wanted to control the spread of the surrealist label. That was the beginning of his systematic planning of international surrealist exhibitions and lectures all over Europe. ${ }^{67}$

\section{Insert Figure 6 and Figure 7}

When it comes to plastic arts and styles, an interesting gap can be noted between Paris and abroad. In Paris, surrealism would praise "the return of automatism" - as Breton and his associates had finally agreed since 1925-26 to define a "surrealist painting". But abroad, things were different: "dalinism" was the trend.

Why dalinism? Already in 1929, in Spain, a critic explained that part of the Catalan youth who was amazed by the instant success of their compatriot, had turned into "dalinism":

What is tragic in the question is the influence Salvador Dalí is starting to have, not upon himself, but upon other creatures. Today, there are youths who turn to Dalínism and play at surrealism. The results are terrible. So far all the imitations in the style and design of J.V. Foix we read, were a calamity. Young theorists, when they talk about art, cannot but copy Dalí's "putrefactions." Everyone who wants is younger. And now, above all, to reach the Dalí 
painting style or the literary style of Foix, a preparation is needed that does not require four days. ${ }^{68}$

These young Catalan painters had understood, despite the critic's dismissal, that dalinism enabled one to efficiently convert an academic career into an avant-garde one. To paint as Dalí indeed, one needed to be trained in the most traditional techniques of representation. But four days could be sufficient after four years of academic training.

In Paris, the situation was totally different. Dalinism as a new pictorial practice remained rare. Neither Ernst, nor Miró, nor Magritte and even less Tanguy wanted to imitate the unbearable Dalí. The "anxiety of influence" which is so characteristic of the avantgardes ${ }^{69}$ was strong in Paris since everyone knew everyone. Abroad, on the contrary, it was not shameful to imitate Dalí. And it was easy. Reproductions of Dalí's works circulated and the dalínian style was very easy to imitate for a good technician: soft objects, blue skies and deserts, telluric shapes, scatology, photographic realism and smooth fractures. Above all, using the dalinian style enabled one to gain instant recognition as a surrealist, which had become synonymous with avant-garde, just as visual perversion meant immediate public scandal. It also enabled one to recycle academic skills.

\section{Dalinian Peripheral Reconversions, Parisian Adaptation}

In the international avant-garde, then, the production of surrealist figurative paintings increased substantially, from the so-called peripheries to the so-called Parisian center whose vanguardist leaders could no longer control what was happening. Many paintings became extremely detailed, and landscaped were built in a classical way, under a theatrical spotlight and with obsessing objects, as artist could see in Dalí's artworks and their reproductions . Art historian José Vovelle made an inventory and counted 394 "dalinian" plastic works produced by 28 Spanish, Dutch and Swedish artists over the peak growth period between $1935-36 .{ }^{70}$ As her inventory was made at the beginning of the 1990s, much more could be counted today, very probably. In Vovelle's sample, 72\% of works were produced between 1934-38. For Spanish artists who remained in the country, the peak of growth occurred between 1928-36. For Spanish people who emigrated, the peak occurred between 1933-40. For Dutch artists it occurred between 1931-34; for Danish and Swedish people between 1934-40. The dalinian period for the Japanese was spread between 1936-40.

This internationalization was confirmed by the increasing numbers of foreign visitors coming to Dalí in Paris during the artistic season and in his village Cadaqués during Easter and the summer. Dalínism became a selling trend - the dalínian flag among the world of fashion and cosmopolitan aristocracy was envied, between Paris and New York, from the trustees' evenings at MoMA, to Elsa Schiaparelli's fashion shows. ${ }^{71}$

Dalí's international influence demonstrated a divergence of logic between the Parisian and the international field of modernism. It was not André Breton's original Parisian movement that gained influence. This soon became a problem for Breton. Beyond a probable jealousy, the internationalization of dalínism, which was the main factor for the internationalization of surrealism, revealed the fragility of the central position of the Parisian group and its dependence upon its "peripheries". Dalí's repeated pranks, escapades, and 
gaffes, his pro-fascist declarations, and his refusal to even consider complying with the group's discipline, would oblige Breton to exclude him. However, neither in February 1934 (Surrealist trial against Dalí) nor the following years, the group could not decide whether to exclude Dali. Dalí's international reputation counted too much - and he was the main figurehead in the so-called "peripheries" of the Parisian movement, that is to say everywhere outside Paris. Whereas in Paris his position-taking was dismissed and being deliberately controversial, he was praised abroad. At the end of the 1930s, Dalí had become the most visible agent of surrealism, and stood internationally as the movement's representative. Dalí's famous declaration in 1940 sums up this point: "The difference between the surrealists and me, is that I am a surrealist.",72

Nothing seemed to scare Dalí, even antifascism, however much Breton and his friends relied on the clear moral superiority of this political position. In the following years, Breton could not stop the growing tension between Dali's statements in support of Hitler and his central vanguardist position in the international artistic field. The painter was officially expelled from the Parisian movement in January 1939.

\section{The Symbolic Victory of Surrealism and Paris}

Notwithstanding these contradictions, Parisian surrealism won the symbolic battle of the international avant-garde.

In Paris, the Surrealists were galvanized by Dalí's contribution. In 1930, in a letter written to abstract painter Theo Van Doesburg, his colleague Joaquín Torres García expressed the desire to "do something" against surrealism: "We have to take a clear stance against surrealism [...] What we need is an organization that actually does something..." Surrealism was doing something; it even made other avant-gardes think they weren't doing anything.

By trying to unite against the domination of surrealism, the geometrical abstracts confirmed their marginalization in Paris and the international peripheries. Everywhere in Europe, people started to leave the abstract movement and by 1934, the movement Abstraction-Creation became a distant memory. The abstract artists were cleared from the landscape, which could also be seen in the press at the time. Dalí described the situation in a very cruel way in his memoirs, backdating the destruction process of the abstract movement to 1929:

In only one single night [after Un Chien andalou], ten post-war years of pseudo-intellectual avant-gardism [were destroyed]. This horrible thing that used to be called abstract art or non-figurative art fell apart under our feet. It was wounded to death and couldn't stand up on its feet anymore after seeing the eye of a young girl being cut in half by a razor, at the beginning of our movie. There was no more room for M. Mondrian's small maniac diamonds in Paris. $^{74}$

Of course, artistic circulations and imitations, and Dalí's impact were not the sole factors for surrealism's victory in Paris. After 1934, the redistribution of the French cultural 
field according to political affinities had a favorable impact on the preservation of the surrealist purity. It contributed to strengthen their Parisian domination. To be against the surrealists, was to be pro-fascist. From this point on, the avant-garde, the social elite, money and left-wing politics were closely linked. In 1931, for instance, it could be difficult to justify the link between the sale of Paul Éluard's and Breton's collections, and the Colonial Exhibition. Surrealists were known as the leaders of "the colonial counter-exhibition", 75 but their private collections contained "primitive objects" bought at low prices, which the surrealists sold and contributed to the promotion of ${ }^{76}$ However, from 1934 the presence of these objects in the market was considered normal. In a letter to his dealer written in 1934, Miró admitted that:

André Breton loved a pastel very much. I thought it was politically judicious to be in good terms with him, because surrealists became official key figures in Paris. [My dealer] Pierre agreed with me, so I offered Breton this pastel. ${ }^{77}$

Internationally, the recognition of surrealism by international museums came at the expense of the abstract movement. In 1934, the works of the surrealists were exhibited at the Brussels Palais des Beaux-Arts, in the United States, and in the Kunsthaus of Zurich. ${ }^{78}$ In Zurich, the 1934 exhibition was entitled Abstrakte Malerei und Plastik: Hans Arp, Max Ernst, Alberto Giacometti, José Gonzalez, Juan Miró; not a single abstract geometric painter was represented, suggesting that geometrical abstraction had no importance in the international artistic field of the time. With the Fantastic Art, Dada, and Surrealism exhibition held at the Museum of Modern Art in New York in 1936, surrealism became part of History. It was then known as the movement which followed Dada directly, as if Dada had not had also abstract and constructivist offspring. This genealogy was scientifically introduced. It ensured the legitimating process of the surrealist story. As for geometrical abstraction, it disappeared a long time from art history: Few art historians have been interested in writing on AbstractionCreation, and no museum dedicated proper exhibitions to it, except in 1978 and $2013 .{ }^{79}$ When Max Ernst painted his L'Ange du foyer (Le Triomphe du Surréalisme) in 1937, surrealism had indeed won the competitive battle of symbolic domination over the international avant-garde field (Figure 8) With no barriers on the horizon and no obstacles in sight, the Parisian surrealists could henceforth forget the peripheral and very recent origin of their international ascendency.

Insert Figure 8 here

\section{Conclusion}

The centre-periphery approach, which is so essential to the canonical narrative of avantgarde art in the $20^{\text {th }}$ century, is based on dubious but common methodologies that dominate our discipline: the monograph, nationalism and ethnocentrism, and evolutionist formalism. Other methods can afford decentred and more historically complex narratives. Combining global, circulatory, and local scales, we can study the history of artistic centralities in the Interwar period outside the myth of Paris as A Moveable Feast (Ernest Hemingway) ${ }^{80}$ where the most innovative forms of creation were supposed to take place. A global, transnational 
history of modern art in the 1920s, which begins by measuring, comparing, and charting objects of study at a global and horizontal ${ }^{81}$ level, before looking at the transnational/ translocal circulation of artworks and artists, and finally analyzing the works and texts themselves, leads to the conclusion that there was a general disenchantment vis-à-vis Paris among international innovative artists until the end of the 1920s. Not only was the constructivist transnational field more attractive, but also artists could find real markets for modern art and applied arts locally.

After 1930, growing disinterest in constructivism gained artistic networks in countries where this tendency had reached a peak of recognition and professionalization. In addition, conservative and fascist tendencies discouraged many artists from staying in their homecountry. Gradually, peripheral artists got interested in Parisian surrealism which had remained until then an exclusively French-speaking literary movement. In the context of the Great Depression, Dalí's success in Paris and abroad triggered soon more interest in surrealism. Whereas in 1929, a majority of European artists still sought to place themselves amongst the avant-garde by way of cubism, futurism, or constructivist practices, by 1934, surrealism had replaced these currents to become a sure-fire route to the avant-garde. But artists sought to imitate the Catalan Dalí more than any other. They followed a Spaniard, not a Parisian. This reversal in symbolic and geocultural fortunes points to various phenomena linked to international circulation and a series of fascinating processes of resemanticization, wherein the 'periphery' manipulated the 'centre' and the losers of the past but close history of modern art asserted themselves as the victors of the avant-garde.

The internationalization of dalinism generalized an interesting social and aesthetical process which was not expected in the 1930s: formerly academic artists from the 'peripheries' could suddenly transition overnight to members of the avant-garde and therefore to the 'centre', and all this without a gradual conversion or the blessing of avant-garde leaders. This was a symbolic revolution that represented nothing less than the revenge of the provinces and of the petit-bourgeois, a revolution that proved that desires for aesthetic quick recognition and local efficient scandal could carry just as much weight in the aesthetic arena as sophisiticated artistic theories and practices. Here was a revolution that was fuelled by everything but the monocentric ideology and the canon of the avant-garde.

This work has received support of TransferS (laboratoire d'excellence, program "Investissements d'avenir" ANR-10-IDEX-0001-02 PSL* and ANR-10-LABX-0099).

BÉATRICE JOYEUX-PRUNEL is maître de conferences in modern and contemporary art at the Ecole normale supérieure in Paris / université Paris Sciences Lettres, with an Habilitation à diriger les recherches - an equivalent of Professor in Modern and Contemporary Art History. She teaches and works on the history of nineteenth and twentieth century art, the global history of the avant-gardes, the visual culture of petroleum, and the digital turn in the humanities with a special focus on social, global, quantitative, and digital approaches. JoyeuxPrunel has founded and manages Artl@s since 2009 (www.artlas.ens.fr). Amongst her publications, the books: Nul n'est prophète en son pays ? l'internationalisation de la peinture des avant-gardes parisiennes, 1855-1914 (Paris: Nicolas Chaudun/ Musée d'Orsay, 2009 Prix du musée d'Orsay); L'Art et la mesure : histoire de l'art et et méthodes quantitatives, 
sources, outils, bonnes pratiques (Paris: Editions Rue d'Ulm, 2010); Thomas DaCosta Kaufmann, Catherine Dossin, and Béatrice Joyeux-Prunel, ed., Circulations in the Global History of Art (New York: Routledge, 2015). More recently she published a pocket-book transnational and social reassessment of modern art history - Les Avant-gardes artistiques. Une histoire transnationale - Vol. 1: 1848-1918 (Paris: Gallimard, Folio Histoire Series, 2016); Vol.2 : 1918-1945 (Paris: Gallimard, Folio Histoire, 2017); Vol. 3: 1945-1968 (Paris, Gallimard, Folio Histoire, forthcoming 2018).

${ }^{1}$ Very representative, and often quoted to endorse this idea, is the book written by Martica Sawin, Surrealism in exile and the beginning of the New York school (Cambridge, Mass.: MIT Press, 1995).

${ }^{2}$ See, Anna Boschetti, Ismes. Du réalisme au postmodernisme (Paris : CNRS Éditions, coll. « Culture \& société », 2014).

3 Irving Sandler, The Triumph of American Painting: A History of Abstract Expressionism (New York: Harper and Row, 1977), and Serge Guilbaut, How New York Stole the Idea of Modern Art: Abstract Expressionism, Freedom, and the Cold War, translated by Arthur Goldhammer (Chicago: University of Chicago Press, 1983).

${ }^{4}$ James Elkins, ed., Is Art History Global? (New York; London: Routlegdge, 2007); Kitty Zijlmans and Wilfried van Damme, World Art Studies: Exploring Concepts and Approaches (Amsterdam: Valiz, 2008).

${ }^{5}$ Mari Carmen Ramírez and Héctor Olea, eds., Inverted Utopias: Avant-Garde Art in Latin America (New Haven: Yale University Press, 2004).

${ }^{6}$ The Social field is defined, after Pierre Bourdieu, as a relatively autonomous sector of the social world, a site of constant negotiation and conflict driven by its own logics, hierarchies, values, legitimization and reproduction processes. Pierre Bourdieu, The Rules of Art: Genesis and Structure of the Literary Field, trans. Susan Emanuel (Stanford: Stanford University Press, 1996). Original version : Les règles de l'art : genèse et structure du champ littéraire (Paris : Le Seuil, 1992).

${ }^{7}$ Béatrice Joyeux-Prunel, Géopolitique des avant-gardes artistiques 1919-1939. Thèse d'Habilitation à diriger les recherches, Paris, Sciences Po, 2015 ; and Béatrice Joyeux-Prunel, "Provincializing Paris. The Center-Periphery Narrative of Modern Art in Light of Quantitative and Transnational Approaches," Artl@s Bulletin, 4, N. 1 (2015): Article 4 ; http://docs.lib.purdue.edu/artlas/vol4/iss1/4/.

${ }^{8}$ Béatrice Joyeux-Prunel, “¿Exponer al cubista sin cubismo? De cómo Kahnweiler llegó a convencer a Alemania - e incluso al mundo entero- del aura de Picasso mediante su pedagogía expositiva (1908-1914)”, Picasso. Registros Alemanes (exh. cat. Malagá: Picasso Museum (Fall 2015)), 258-273.

${ }^{9}$ Piet Mondrian, letter to Theo van Doesburg, 9 Februrary 1920, quoted by Susanne Deicher, Piet Mondrian: Protestantismus und Modernität (Berlin: Reimer, 1995), 197.

${ }^{10}$ Norbert Bandier, Sociologie du surréalisme (Paris : La Dispute, 1999).

${ }^{11}$ Susanne Deicher, Piet Mondrian. Protestantismus und Modernität (Berlin: Reimer, 1995), 197.

12 Béatrice Joyeux-Prunel, Les avant-gardes artistiques 1848-1918. Une histoire transnationale (Paris: Gallimard, 2016, Folio Histoire Series N. 149). See also Catherine Dossin and Béatrice Joyeux-Prunel, "The German Century. Towards a Geopolitical Art History", in: Thomas Da Costa Kaufmann, Catherine Dossin, and Béatrice Joyeux-Prunel, 
eds., Circulations. Writing the Global History of a Globalized Art (New York: Routledge, 2015), 183-201.

${ }^{13}$ See Kenneth Silver, Esprit De Corps: The Art of the Parisian Avant-Garde and the First World War, 1914-1925 (Princeton, N.J.: Princeton University Press, 1992).

${ }^{14}$ Correspondência Mário de Andrade \& Tarsila do Amaral, (São Paulo: EdUSP, 1999); and Tarsila Viajante / Viajera, exhibition catalogue São Paulo, Pinacoteca, Secretaria de Estado da Cultura, Governo do Estado de São Paulo, 19 January-16 March 2008, Buenos Aires, Museo de Arte Latinoamericano de Buenos Aires, 27 March-2 June 2008, Regina Texeira de Barros ed. (Câmara Brasileira do Livro, Malba, Fundación Costantini, 2008).

${ }^{15}$ Béatrice Joyeux-Prunel, Géopolitique des avant-gardes artistiques 1919-1939. See also Béatrice Joyeux-Prunel, Les avant-gardes artistiques. Une histoire transnationale

16 “À Paris tout est totalement mort, [...] C'est pour moi un fait certain que la nouvelle zone de culture est le Nord." Théo Van Doesburg, letter to a friend. Michel Seuphor, Piet Mondrian (Paris: Séguier, 1987), 127.

${ }^{17}$ He took part in the collective exhibition in 1919 (August-September) in London ("Exhibition of French Art 1914-1919," Mansard Gallery, Heal \& Son, Ltd., London ); personal touring exhibition in Geneva, Dresden, Munich, Düsseldorf, and New York (November 1919-December 1921 : “Tournée de l'exposition de sculptures, sculpto-peintures, peintures, dessins de Alexandre Archipenko"), before a personal exhibition in the Russian Pavilion of the Venice Biennale 1920.

${ }^{18}$ Art critic Theodor Däubler wrote several texts on Archipenko who exhibited at Fritz Gurlitt's Gallery in Berlin, and with other German artists such as Lyonel Feininger in Frankfurt am Main in May 1922.

${ }^{19}$ His architectonic art found echoes in the works of Central European sculptors, such as Katarzyna Kobro. The first issue of the constructivist journal MA, edited by László MoholyNagy after his arrival at the committee of the hungarian vanguardist journal was dedicated to Archipenko (MA, N. 6, Vienna 1921). Archipenko's works were displayed at the Zenit 1922 exhibition in Zagreb and in Belgrade (1923). See Krisztina Passuth, Les Avant-gardes de l'Europe centrale 1907-1927 (Paris: Flammarion, 1988), 183 and 219.

${ }^{20}$ Donald H. Karshan, ed., Archipenko: international visionary, (Washington: Published for the National Collection of Fine Arts by Smithsonian Institution Press, 1969),72.

${ }^{21}$ Detailed research presented in Béatrice Joyeux-Prunel, "Provincializing Paris...".

${ }^{22}$ See for instance Francis Picabia's and André Breton's letters to Tristan Tzara, in Michel Sanouillet ed., Dada à Paris, revised and reedited by Anne Sanouillet (Paris: Éditions du CNRS, 2005).

${ }^{23}$ This is the result of a study of 27 modernist magazines available in the Centre Pompidou Library, concentrating on three important years, 1924-6. See Béatrice JoyeuxPrunel, "Provincializing Paris..."

${ }^{24}$ Camille Mauclair, L'Architecture va-t-elle mourir? (Paris : Éditions de la Nouvelle Revue critique, n. d.) 36. Quoted in Yves Chevrefils Desbiolles, Les revues d'art à Paris 1905-1940 (Paris : Ent'revues, 1993), 95.

${ }^{25}$ Macel, Otakar, "L'Esprit nouveau à Prague", in Stanislaus von Moos, ed., L'Esprit nouveau. Le Corbusier und die Industrie 1920-1925 (Berlin : W. Ernst und Sohn, 1987) 160163, and Jean-Louis Cohen, "Avant-gardes et revues d'architecture en Russie, 1917-1941", Revue de l'art, N. 89, 1990, 29-38.

26 The plan to send Fernand Léger to establish contacts was not fulfilled and the American edition project was abandoned. Mardges Bacon, Le Corbusier in America: Travels in the Land of the Timid (Cambridge, Mass.; the MIT Press, 2001). 
${ }^{27}$ Ludwig Hirschfeld-Mack, The Bauhaus. An Introductory Survey (Croydon: Victoria, Longmans Green, 1963), 2-3, quoted by Igor Naoumovitch Golomchtok, L'art totalitaire: Union soviétique, IIIe Reich, Italie fasciste, Chine (translated from the English by Michèle Levy-Bram. Paris : Carré, 1991), 27.

${ }^{28}$ Marie-Aline Prat, Peinture et avant-garde au seuil des années 30 (Lausanne: L'Âge d'homme, 1984).

${ }^{29}$ Such as the galleries Povolozky, Viscontin, galerie d'Art contemporain, Le Sacre du Printemps, Marck...

${ }^{30}$ On this xenophoby see L'École de Paris 1901-1929, exh. cat., Sophie Krebs ed., Paris, Musée d'art moderne de la Ville de Paris, 2000 (Paris: Réunion des Musées nationaux, 2000).

${ }^{31}$ Félix Marcilhac, József Csáky: du cubisme historique à la figuration réaliste: catalogue raisonné des sculptures (Paris: Éditions de l'Amateur, 2007).

${ }^{32}$ On this naturalist shift see Romy Golan, Modernity and Nostalgia: Art and Politics in France Between the Wars (New Haven and London: Yale University Press, 1995).

${ }^{33}$ See Cercle et Carré and the International Spirit of Abstract Art, exh. cat. Athens, Georgia, Georgia Museum of Art, University of Georgia, 12 October 2013-5 January 2014 (Athens, Georgia: Georgia Museum of Art, University of Georgia, 2013).

${ }^{34} \mathrm{http} / / / \mathrm{www}$.salvador-dali.org/cataleg_raonat/

${ }^{35}$ Salvador Dalí, Letter to his uncle Anselm Domènech, Summer 1919, quoted in Ian Gibson, The shameful life of Salvador Dali (New York: W.W. Norton, 1998), 104.

${ }^{36}$ Dalí, Personnage à la fenêtre, 1925, Madrid, Museo National Centro de Arte Reina Sofia.

${ }^{37}$ Ian Gibson, The Shameful Life of Salvador Dali, 172.

${ }^{38}$ Dalí, Nature morte (invitation au sommeil), 1926, present whereabouts unknown.

39 Salvador Dalí, Académie néo-cubiste, 1926, Museo de Montserrat, Montserrat. Specialists have recognized an inspiration from Picasso's Atelier à la tête de plâtre (1925) that Dalí saw in Picasso's studio while visiting the Parisian painter in Spring 1926. But one has also to point out the constructivist and post-cubist inspirations of the painting, which also includes a clear reference to Jean Arp's arbitrary color shapes.

${ }^{40}$ Ian Gibson, The Shameful Life of Salvador Dali, 200.

${ }^{41}$ The final list of referencial personalities (a theoretical obligation for a manifesto) is the following: Picasso, Gris, Ozenfant, de Chirico, Miró, Lipchitz, Brancusi, Arp, Le Corbusier, Reverdy, Tzara, Éluard, Aragon, Desnos, Maritain, Raynal, Zervos, Breton, Cocteau, Stravinsky, García Lorca.

${ }^{42}$ Ian Gibson, The Shameful Life of Salvador Dali, 212.

${ }^{43}$ Guash dans L'Amic de les Arts, October 1926, quoted in Ian Gibson, The Shameful Life of Salvador Dalí, 220.

${ }^{44}$ L'Amic de les Arts, quoted in Ian Gibson, The Shameful Life of Salvador Dalí, 221.

${ }^{45}$ See René Girard, Mimesis and Theory: Essays on Literature and Criticism, 19532005, Robert Doran ed. (Stanford: Stanford University Press, 2008). For instance, in December 1929, the "Collection of our nowadays paintings, which belong to Serge Lifar", which included works from Miro, was shown in the Madeleine quarter. Introduction written by Jean Cocteau.

${ }^{46}$ Miró to Dalí, November 1927, in Joan Miró 1917-1934: la naissance du monde, exh. cat. Paris, Centre Pompidou, 3 March-28 June 2004, Agnès de la Beaumelle ed. (Paris : Centre Pompidou, 2004), 333.

${ }^{47}$ Interview for Estampa, 6 November 1928, quoted in Ian Gibson, The Shameful Life of Salvador Dalí, 239 
${ }^{48}$ The most detailed history of surrealism is Gérard Durozoi, Histoire du mouvement surréaliste (Paris: Hazan, 2004).

${ }^{49}$ In 1927 Marie Laure de Noailles boughtMax Ernst's painting Monument aux oiseaux just after completion. See Laurence Benaïm, Marie Laure de Noailles : la vicomtesse du bizarre (Paris: Grasset, 2001), 170.

${ }^{50}$ See Luis Buñuel, "L'âge d'or" : correspondance Luis Buñuel-Charles de Noailles : lettres et documents, 1929-1976, Jean-Michel Bourhous and Nathalie Schoeller eds., Cahiers du Musée national d'art moderne (Paris: Centre Georges Pompidou, 1993), 31.

${ }^{51}$ See Marijke Verhaar, Salvador Dalí et le mécénat du Zodiaque, unpublished doctoral thesis (Utrecht University, 2008).

52 The Noailles first commissioned De Stijl's artists to design the interior of their house Villa Saint-Bernard; then, they commissioned a renewed interior for their private Parisian mansion, Place des États-Unis, from Jean-Michel Frank.

${ }^{53}$ Dominique Paulvé, Marie Cuttoli: Myrbor et l'invention de la tapisserie moderne (Paris: Norma, 2010).

${ }^{54}$ Louis Aragon and André Breton, "ProtestATION," La Révolution surréaliste N. 7 (June 1926), 31.

${ }^{55}$ Shane Maree Dunworth, The de Noailles as collectors and patrons, unpublished $\mathrm{PhD}$ thesis (London: Courtauld Institute of Art, 1984), 36; Malcolm Gee, Dealers, Critics, and Collectors of Modern Painting: Aspects of the Parisian Art Market Between 1910 and 1930 (New York: Garland Publishings, 1981); Béatrice Joyeux-Prunel, Les avant-gardes artistiques 1918-1945. Une histoire transnationale.

56 “L'Envol." Un remarquable ensemble-sport, créé par Norine. Psyché, August 1927, Brussels, Photograph by Robert De Smet. Bibliothèque Royale de Belgique. In the background, a Max Ernst painting, Forêt, is displayed behind the fashion model (1927).

${ }^{57}$ Translated from the French, Salvador Dalí, La vie secrète de Salvador Dalí, Salvador, Michel Déon ed. (Paris: La Table ronde, 1952), 161.

58 "Actuellement les collections privées les plus célèbres de Paris possèdent des œuvres du peintre de Cologne [...], celles d'Alphonse Kann, du comte de Beaumont, du vicomte de Noailles, du baron Napoléon Gourgaud, de Raoul La Roche, Kélékian, Jacques Doucet, tous ceux qui collectionnent Picasso et les autres grands cubistes, auxquels ils ont joint Paul Klee, Félix Fénéon qui découvrit Seurat [...]." Quoted in Werner Spies, Max Ernst: les collages, inventaires et contradictions, translated from the German by Eliane Kaufholz (Paris: Gallimard, 1984), 129 (note 656).

${ }^{59}$ Lioubomir Mitsitch [sic], Les Chevaliers de Montparnasse (Paris: aux Arènes de Lutèce, 1932).

${ }^{60}$ This exhibition is not well known. I thank Gabriela Francone for introducing me to the work of Antonio Berni.

${ }^{61}$ André Breton, Le surréalisme et la peinture, avec 77 photogravures d'après Max Ernst, Giorgio de Chirico, Joan Miró, Georges Braque, Arp [sic], Francis Picabia, Pablo Picasso, Man Ray, André Masson, Yves Tanguy, Paris, libr. Gallimard, 1928 (New edition Paris: Gallimard Folio Essais, 2002); English translation by Simon Watson Taylor, Surrealism and Painting (London: Macdonald and Co., 1972).

${ }^{62}$ On this question see Béatrice Joyeux-Prunel, Les avant-gardes artistiques 19181945. Une histoire transnationale .

${ }^{63}$ André Breton, Le surréalisme et la peinture, avec 77 photogravures d'après Max Ernst, Giorgio de Chirico, Joan Miró, Georges Braque, Arp [sic], Francis Picabia, Pablo Picasso, Man Ray, André Masson, Yves Tanguy (Paris: librairie Gallimard, 1928 ; new edition Paris: Gallimard, coll. Folio essais $n^{\circ}$ 399, 2002). 
${ }^{64}$ André Breton, "Le surréalisme et la peinture », La Révolution surréaliste $\mathrm{N}^{\circ}$ 6, Year 2, 1 March 1926, 20. «Le scandale continu du cézannisme, du néo-académisme ou du machinisme ».

${ }^{65}$ La part du jeu et du rêve: Óscar Domínguez et le surréalisme, 1906-1957 (exhibition catalogue, Marseille, Musée Cantini, 25 June - 2 October 2005 ; Paris: Paris, Hazan, 2005).

${ }^{66}$ André Breton, talk at the Circulo de amistad XIV abril, Tenerife, 23 May 1935. Manuscript p. 2. Archive André Breton.

${ }^{67}$ The planning can be found in Breton's Archive: André Breton, "Projet de cycle de conférences - L'heure nous paraît venue d'interrompre en public...», June 1925. http://www.andrebreton.fr/work/56600100453590.

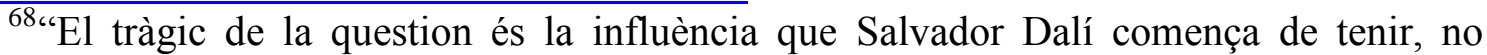
damunt d'ell mateix, sinó damunt d'altres criatures. Avui hi ha xicots que passen el dalinisme I juguen a surrealism. Els resultants són terribles. Fins ara totes les imitacions a l'estil i la concepció de J. V. Foix que hem llegit, eren una calamitat. Els teoritzadors joves quan parlen d'art, d'En Dalí només saben copier-ne les "putrefaccions". De jove n'és tothom que vol. I, sobretot, que per arribar a l'estil pictòric de Dalí o a l'estil literari de Foix cal una preparació que no s'adquireix amb quatre dies." XXX, « Dalinisme », La Nova Revista, vol. VII, n²8, April 1929, 310.

${ }^{69}$ Harold Bloom, The Anxiety of Influence: A Theory of Poetry (London, New York: Oxford University Press, $1975 ; 2^{\text {nd }}$ ed. 1997).

${ }^{70}$ José Vovelle, "Une Europe surréaliste: Dalinisme et Daliniens", in L'Europe surréaliste, contributions au colloque de Strasbourg (Septembre 1992), Henri Béhar ed. (Lausanne: l'Âge d'Homme : Mélusine: cahiers de recherches sur le surréalisme, N.14, 1994), 111-120.

${ }^{71}$ See some fashion pictures made by photographer Cecil Beaton (1904-1980), for instance his "Models wearing wool suits by Elsa Schiaparelli with Salvador Dalí-inspired bureau-like pockets". Vogue (US edition), 15 September 1936.

72 Dictionnaire général du surréalisme et de ses environs, Adam Biro and René Passeron ed. (Paris: Presses universitaires de France ; Fribourg: Office du livre, 1982), 114.

73 "Il faut absolument que nous prenions contre-position [...] ce qu'il nous faut est un groupement qui fait quelque chose...". Letter, undated, archives of the Torrès family, quoted by Marie-Aline Prat, Peinture et avant-garde au seuil des années 30 (Lausanne: l'Âge d'Homme, 1984, 34 and 43 note 25).

${ }^{74}$ Salvador Dalí, La Vie secrète de Salvador Dalí, 171.

${ }^{75}$ Sophie Cazaumayou, Objets d'Océanie. Regards sur le marché de l'art primitif en France (Paris: L'Harmattan, 2007), 107-108.

${ }^{76}$ Sophie Leclercq, "The Surrealist Appropriation of the 'indigeneous' art", Arts et Sociétés, 23 November 2006. http://www.artsetsocietes.org/a/a-leclercq.html

${ }^{77}$ Miró to Pierre Matisse, Barcelona, 17 December 1934 (Joan Miró la naissance du monde, 1917-1934, 368).

${ }^{78}$ Abstrakte Malerei und Plastik: Hans Arp, Max Ernst, Alberto Giacometti, José Gonzalez, Juan Miró, 11 October-14 November 1934.

${ }^{79}$ Abstraction-Création, 1931-1936, exh. cat. Münster, Westfälisches Landesmuseum für Kunst und Kulturgeschichte, Landschaftsverband Westfalen-Lippe, Münster, 2 April-4 June 1978, and Musée d'art moderne de la Ville de Paris, 16 June-17 September 1978 (Münster:Westfälisches Landesmuseum für Kunst und Kulturgeschichte des Landschaftverbandes-Lippe, 1978); Cercle et Carré and the International Spirit of Abstraction (Georgia Museum of Art, 2013).

${ }^{80}$ Ernest Hemingway, A moveable feast (New York : C. Scribner's sons, 1964). 
Peripheral Circulations, Transient Centralities

${ }^{81}$ To quote the late Piotr Piotrowski in his introduction to In the Shadow of Yalta. Art and the Avant-garde in Eastern Europe, 1945-1989 (London: Reaktion Books, 2009). 